\title{
Sporadic pheochromocytoma/secreting paraganglioma
}

INSERM

\section{Source}

INSERM. (1999). Orphanet: an online rare disease and orphan drug data base. Sporadic pheochromocytoma/secreting paraganglioma. ORPHA:276621

Sporadic pheochromocytoma/secreting paragang lioma are isolated, non-familial, catecholamin-producing tumors arising from neuroendocrine chromaffin cells in the adrenal medulla or in extra-adrenal chromaffin tissue, respectively. The majority of these tumors are benign and the presenting symptoms are typically caused by the increased catecholamine production of the tumor, including hypertension (often paroxysmal), tachycardia, anxiety and/or excessive sweating. 